\title{
IN VITRO PROPAGATION OF NEPALESE ORCHIDS: A REVIEW
}

\author{
Jaime A. Teixeira da SILVA ${ }^{1 *}$, Kamal P. ACHARYA ${ }^{2 *}$ \\ ${ }^{1}$ P. O. Box 7, Miki-cho post office, Ikenobe 3011-2, Kagawa-ken, 761-0799, Japan \\ ${ }^{2}$ Department of Biology, Norwegian University of Science and Technology, 7491, Trondheim, Norway
}

Received: May 23, 2014; Accepted: August 17, 2014

\begin{abstract}
Nepalese orchids are made up of 458 taxa. Despite a ban on the collection and trade of all orchid species in Nepal, numerous anthropogenic factors are leading to the rapid loss of natural stands of germplasm. Biotechnology, specifically in vitro propagation, may be the only viable solution for preserving and reintroducing endangered germplasm back into the wild. Despite the large germplasm base, only tissue culture studies have been conducted, and most have focused almost exclusively on in vitro seed germination, the bulk of which have been conducted in the past few years. No other biotechnological advances have yet been made. This brief review provides a short synopsis of the advances made thus far in the in vitro propagation of Nepalese orchids.
\end{abstract}

Key words: in vitro; Nepal; Orchidaceae; seed germination; tissue culture

\section{The use of tissue culture for Nepalese orchids}

The Orchidaceae has an estimated 870 described genera and in excess of 25000 species (Dressler 1993; Swarts \& Dixon 2009). An estimated 458 taxa of orchids are found in Nepal (Rokaya et al. 2013), "including 104 genera, 437 species, 16 varieties, 3 subspecies and 2 forma and 18 endemic species." Such detailed checklists are important to ensure that a solid botanical base of information exists to develop a structured biotechnological and preservation programme. Such a programme would involve the use of tissue culture to preserve and multiply rare germplasm, genetic transformation and molecular breeding to improve weak germplasm by introducing novel or strengthening characters, and traditional to obtain progeny with introduced characters. Wild Nepalese orchids are popularly known by their vernacular names: Sunakhari, Sungava, Jiwanti, Bankera, Thur or Thurjo. Orchids in Nepal have ornamental and medicinal uses (Acharya \& Rokaya 2010; Pant 2013; Pant \& Raskoti 2013; Subedi et al. 2013). Pant and Raskoti (2013) indicated that 90 orchid genera from Nepal have medicinal value.
Most orchids in Nepal are under threat due to overexploitation, illegal trade, habitat loss, deforestation and other anthropogenic-induced stresses (White \& Sharma 2000; Rajbhandari \& Bhattarai 2001; Bajracharya \& Shakya 2002; Acharya et al. 2011; Rokaya et al. 2013). The Nepal Forest Act (1993), Forest Regulations (1995) and its amendment (2001) ban orchids from being collected and traded. Furthermore, Nepal has been a member nation of The Convention on International Trade in Endangered Species of Wild Fauna and Flora (CITES) since 1975 (http://www.cites.org/eng/disc/parties/alphabet.php) and there is ban on collection and trade of all species of orchids which are included in CITES Appendix II. However, these laws, regulations and policies are not effectively implemented since collection and trade are widely reported without restriction, sometimes even sold in open markets of Kathmandu for medicinal use (Acharya \& Rokaya 2005). Contrary to these laws are regulations, such as a bill recently passed by The Government of Nepal on $7^{\text {th }}$ March 2013, which permit the collection of wild orchids for sale and commercial cultivation (MOFSC 2013). 

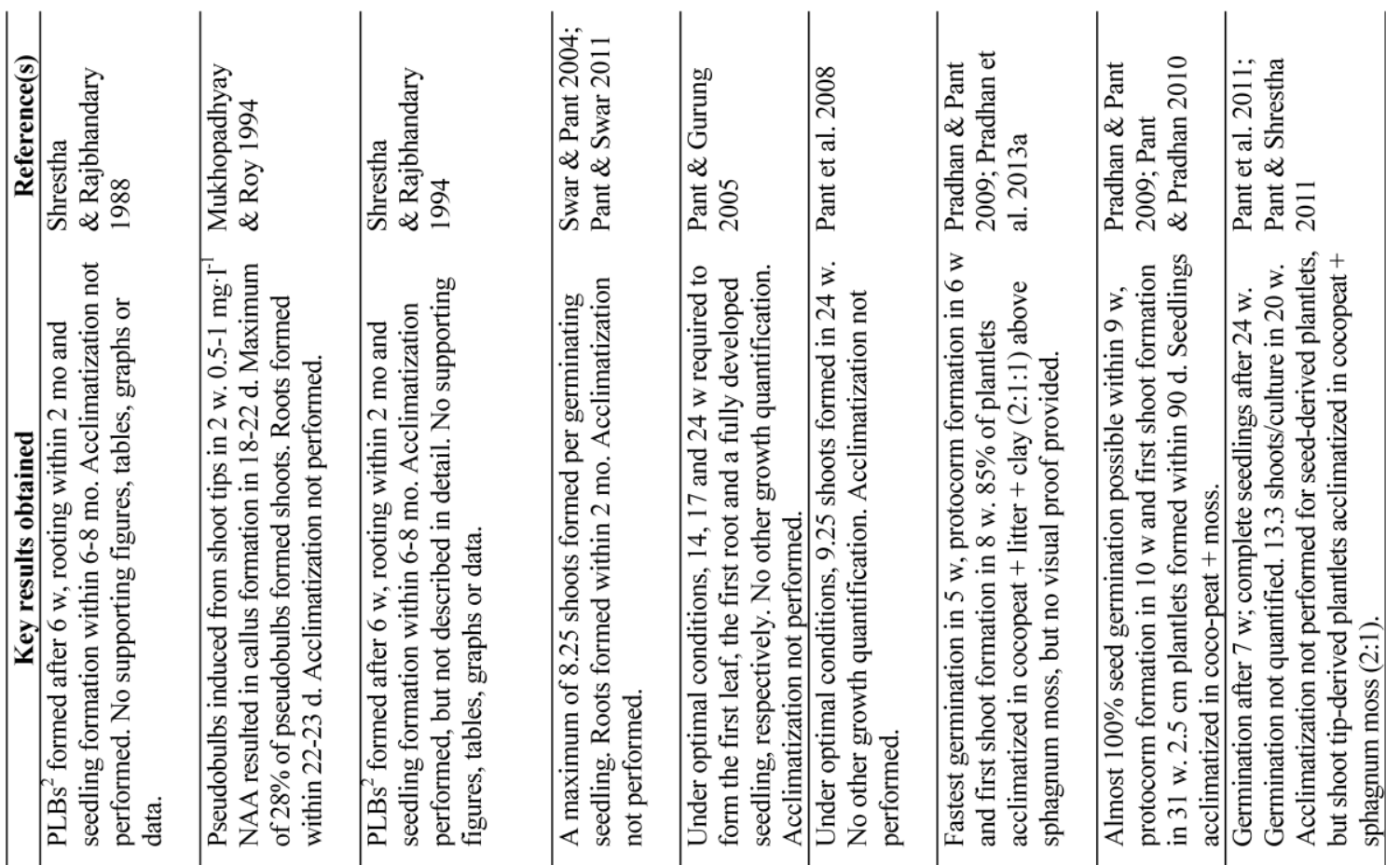

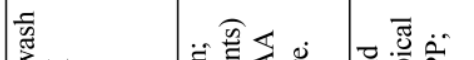

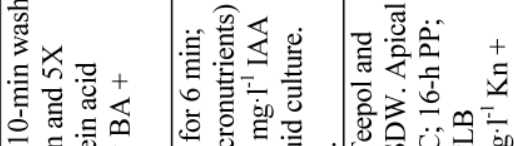

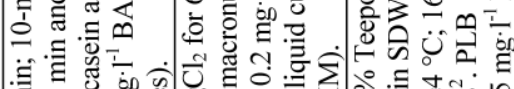

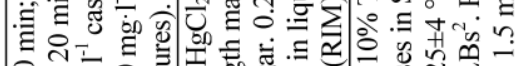

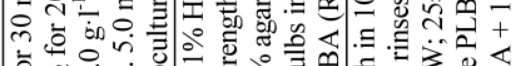

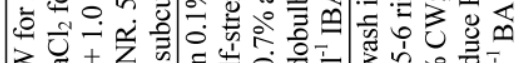

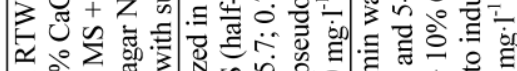

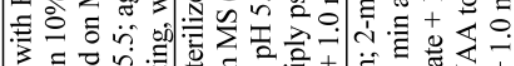

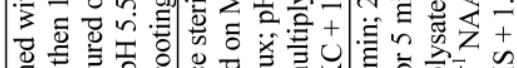

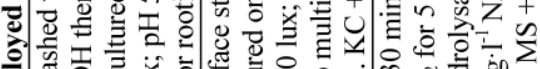

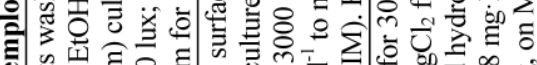

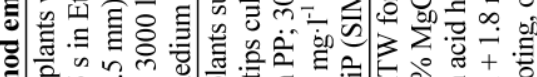

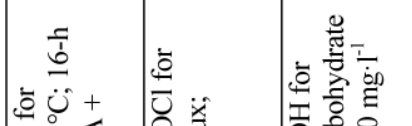

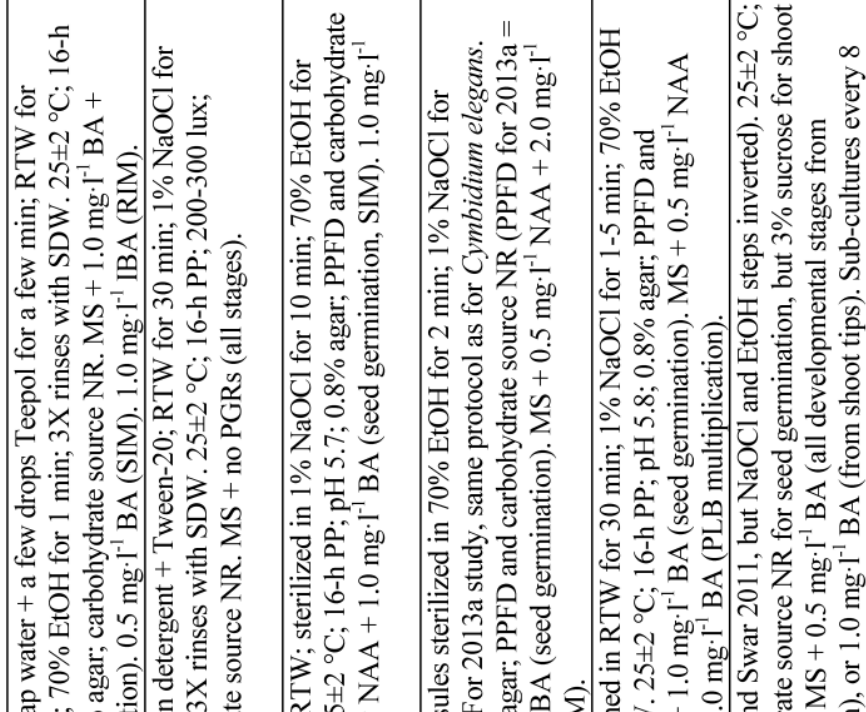

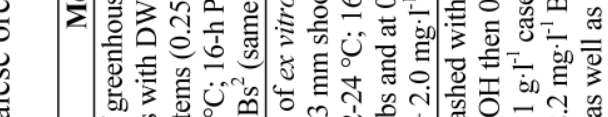

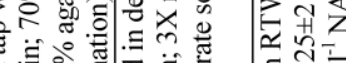

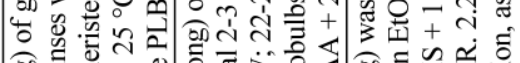
क0.

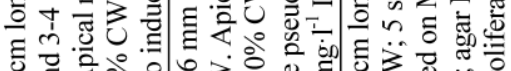

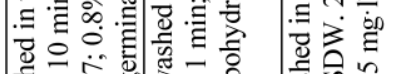

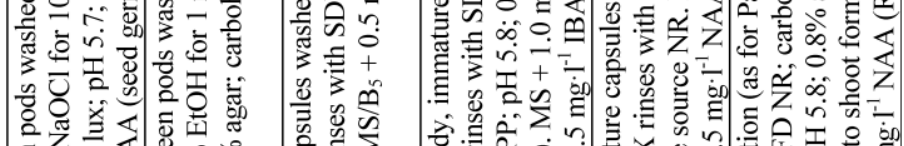

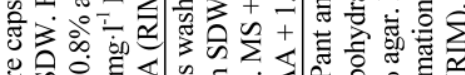

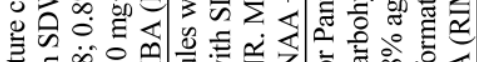

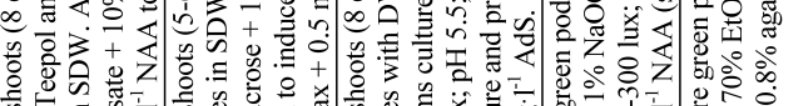
造

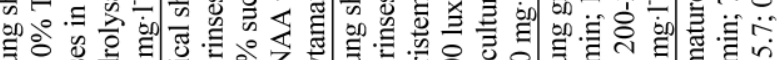

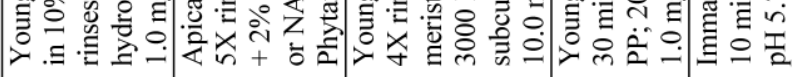

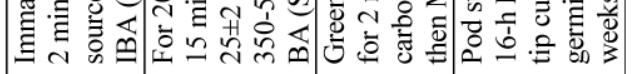

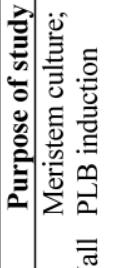

की

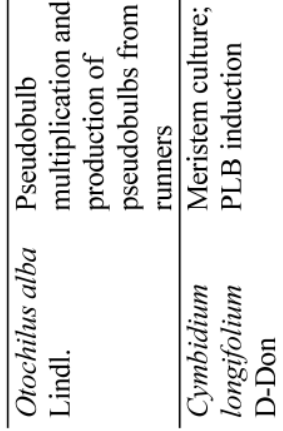

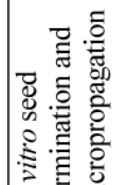
乏总品
焉

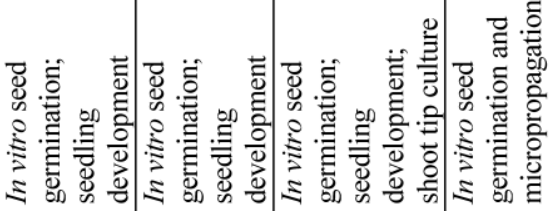

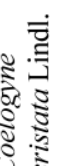

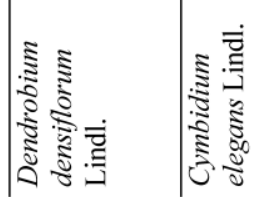

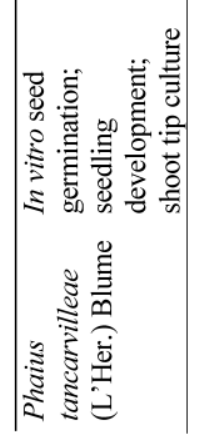




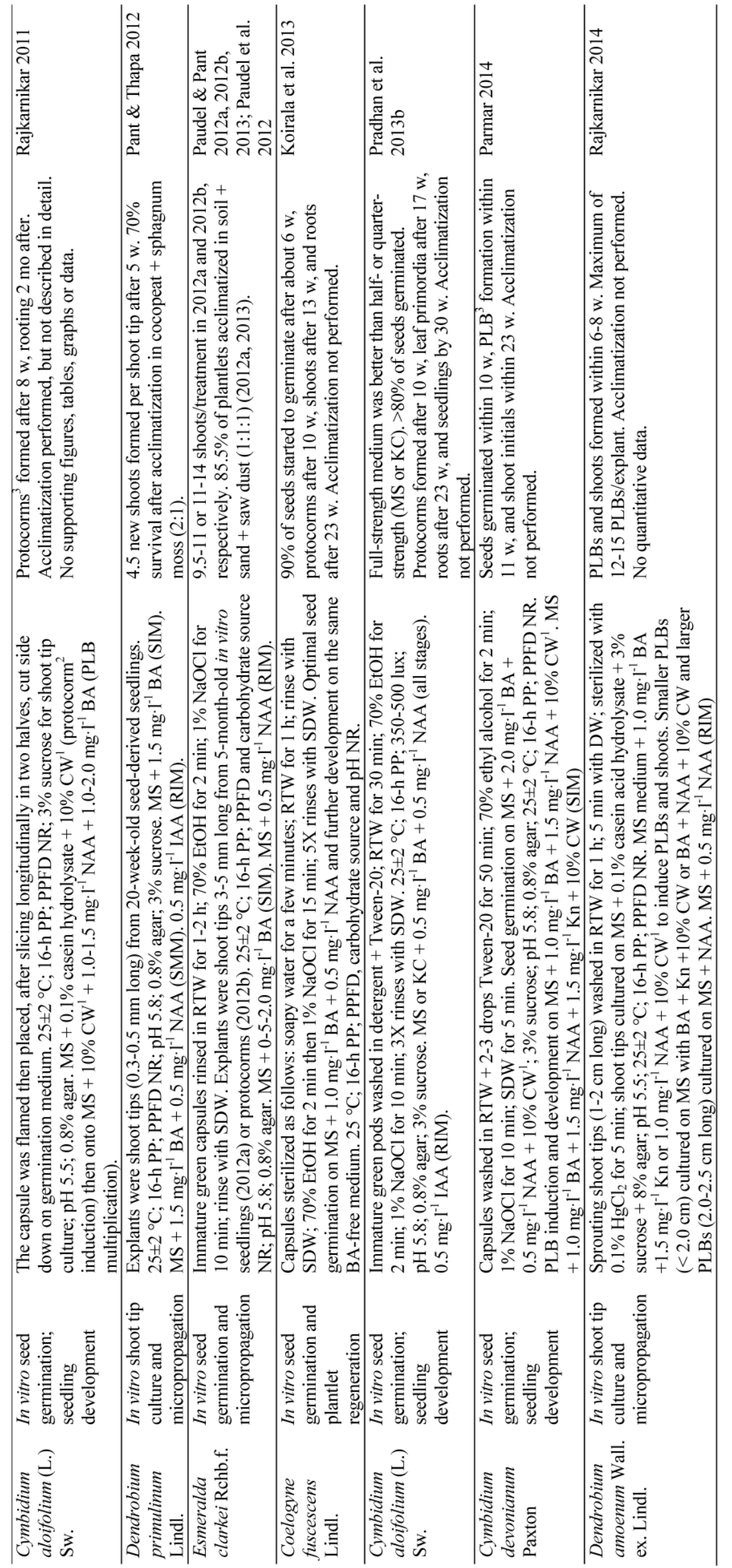

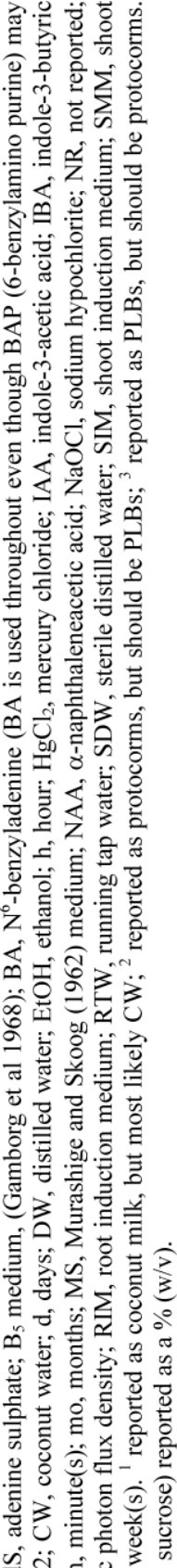

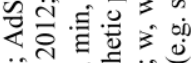

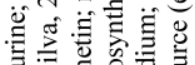

言语章

署

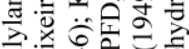

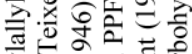

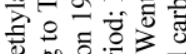

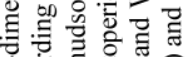

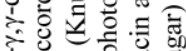

西

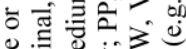

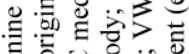

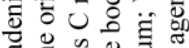

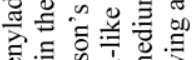

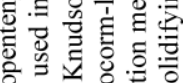

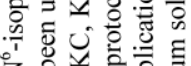

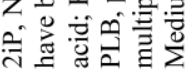


To meet the demand for various uses and to protect endangered Nepalese orchid species, new technologies need to be developed for mass propagation. Biotechnology, including tissue culture, is an essential tool for the preservation of rare or endangered Nepalese orchids with ornamental and medicinal value, and improve their characteristics (Acharya \& Rokaya 2010; Pant 2013, 2014). However, very few studies, outlined herein, have been carried out in this field in Nepal, and most studies have been published in local or relatively unknown journals. The aim of this review is to provide an overview of the biotechnological techniques used to grow and/or preserve Nepalese orchids and to provide some future perspectives.

\section{Conclusions and future vision for Nepalese or- chid biotechnology}

The use of tissue culture for the preservation of Nepalese orchid germplasm has a very recent history, which began in 1988 but intensified after 2009 . Table 1 indicates that tissue culture has been applied to 15 species (in 7 genera), about $3 \%$ of the total of 437 species of Nepalese orchids. Unlike orchids from other locations around the world, including neighbouring India, which already have a rich history of tissue culture and other biotechnological applications (Hossain et al. 2012; Teixeira da Silva 2013), the application of tissue culture to better understanding Nepalese orchids, and preserving or commercializing them, remains relatively unexplored. Table 1 reveals that most studies to date have dealt with in vitro seed germination and seedling production often followed by micropropagation initiated with a seedling explant. Almost all of the studies involve a sterilization procedure for the green pods or capsules and culture on Murashige and Skoog (1962) - MS basal medium in the light. Subsequent development of the protocorms and the induction of protocorm-like bodies in the presence of plant growth regulators characterize most of the studies listed in Table 1. Applied aspects such as synthetic seed technology for cryopreservation (Sharma et al. 2013), genetic transformation (Teixeira da Silva et al. 2011), the use of thin cell layers (Teixeira da Silva 2013) and in vitro flowering (Teixeira da Silva et al. 2014) are all aspects that are unexplored and that would enrich the focus given to this group of as yet poorly understood orchids desperately in need of conservation. The government institution, The Department of Plant Resources (DPR) under Ministry of Forest and Soil Conservation (MOFSC) in coordination with the Central Department of Botany (CDB), Tribhuvan University, have initiated tissue culture of native orchids (KP Acharya, personal observation). However, this type of program needs to be implemented on a larger scale in order to cover the wide germplasm base that is under threat.

\section{Acknowledgements}

The authors thank Dr. Bijaya Pant for providing some of her publications and Mr. Rajendra Acharya for help in finding articles.

\section{REFERENCES}

Acharya K.P., Rokaya M.B. 2005. Ethnobotanical survey of medicinal plants traded in the streets of Kathmandu valley. Scientific World 3(3): 44-48.

Acharya K.P., Rokaya M.B. 2010. Medicinal orchids of Nepal: are they well protected? Our Nature 8. 8291. DOI: $10.3126 /$ on.v8i1.4315.

Acharya K.P., Vetaas O.R., Birks H.J.B. 2011. Orchid species richness along Himalayan elevational gradients. J. Biogeogr. 38: 1821-1833. DOI: 10.1111/j.1365-2699.2011.02511.x.

Bajracharya D.M., Shakya L.R. 2002. Nepalese orchids: its status and systematics. Journal of Natural History Museum 21: 223-242.

Dressler R.L. 1993. Phylogeny and classification of the orchid family. Cambridge University Press.

Gamborg O.L., Miller R.A., Ojima K. 1968. Nutrient requirements of suspension cultures of soybean root cells. Exp. Cell Res. 50: 151-158.

Hossain M.M., Kant R., Van P.T., Winarto B., Zeng S., Teixeira da Silva J.A. 2012. The application of biotechnology to orchids. Crit. Rev. Plant Sci. 32: 69139. DOI: $10.1080 / 07352689.2012 .715984$.

Knudson L. 1946. A new nutrient solution for germination of orchid seeds. Amer. Orch. Soc. Bull. 15(5): 214-217.

Koirala D., Pradhan S., Pant B. 2013. Asymbiotic seed germination and plantlet development of Coelogyne fuscescens Lindl., a medicinal orchid of Nepal. Scientific World 11(11): 97-100. DOI: 10.3126/sw.v11i11.8561. 
MOFSC 2013. Sunakhari Sankalan tatha kheti bikas (Karyabidhi) nirdesika 2069 BS, Kathmandu, Nepal. [in Nepali]

Mukhopadhyay K., Roy S.C. 1994. In vitro induction of 'runner' - a quick method of micropropagation in orchid. Sci. Hortic. 56: 331-337. DOI: 10.1016/03044238(94)90051-5.

Murashige T., Skoog F. 1962. A revised medium for rapid growth and bioassays with tobacco tissue cultures. Physiol. Plant. 15(3): 473-497.

Pant B. 2013. Medicinal orchids and their uses: Tissue culture a potential alternative for conservation. Afr. J. Plant Sci. 7(10): 448-467. DOI: 10.5897/AJPS2013.1031.

Pant B. 2014. Application of plant cell and tissue culture for the production of phytochemicals in medicinal plants. Infectious Diseases and Nanomedicine II. Advances in Experimental and Medical Biology 808: 25-39. DOI: 10.1007/978-81-322-1774-9_3.

Pant B., Gurung R. 2005. In vitro seed germination and seedling development in Aerides odorata Lour. J. Orchid Soc. India 19: 51-55.

Pant B., Pradhan S. 2010. Micropropagation of Cymbidium elegans Lindl. through protocorm and shoot tip culture. Role of biotechnology in food security and climate change. In: Proceedings of 6th International plant tissue culture and Biotechnology conference, Dhaka, Bangladesh, December, pp. 3-5.

Pant B., Raskoti B. 2013. Medicinal orchids of Nepal. Himalayan Map House Pvt. Ltd.

Pant B., Shrestha S. 2011. In vitro mass propagation of a ground orchid - Phaius tancarvilleae (L'Her.) Blume through shoot tip culture. Plant Tiss. Cult. Biotechnol. 21(2): 181-188.

Pant B., Shrestha S., Pradhan S. 2011. In vitro seed germination and seedling development of Phaius tancarvilleae (L'Her.) Blume. Scientific World 9(9): 50-52. DOI: 10.3126/sw.v9i9.5518.

Pant B., Swar S. 2011. Micropropagation of Cymbidium iridioides. Nepal Journal of Science and Technology 12: 91-96. DOI: 10.3126/njst.v12i0.6485.

Pant B., Swar S., Karanjeet A. 2008. Micropropagation of Coelogyne cristata Lindl. J. Orchid Soc. India 22(1-2): 45-48.

Pant B., Thapa D. 2012. In vitro mass propagation of an epiphytic orchid, Dendrobium primulinum Lindl. through shoot tip culture. Afr. J. Biotech. 11(42): 9970-9974. DOI: 10.5897/AJB11.3106.

Parmar G. 2014. In vitro seed germination and seedling development of Cymbidium devonianum Paxton (Orchidaceae). Bull. Dept. Plant Res. 36: 61-64.
Paudel M.R., Pant B. 2012a. In vitro micropropagation of rare orchid (Esmeralda clarkei Rchb.f.) from shoot tip section. International Journal of Biology, Pharmacy and Allied Sciences 1(11): 1587-1597.

Paudel M.R., Pant B. 2012b. In vitro plant regeneration of Esmeralda clarkei Rchb.f. via protocorm explant. Afr. J. Biotechnol. 11(54): 11704-11708. DOI: 10.5897/AJB12.985.

Paudel M.R., Pant B. 2013. A reliable protocol for micropropagation of Esmeralda clarkei Rchb. f. (Orchidaceae). Asia Pacific J. Mol. Biol. Biotechnol. 21(3): 114-120.

Paudel M.R., Pradhan S., Pant B. 2012 In vitro seed germination and seedling development of Esmeralda clarkei Rchb. f. (Orchidaceae). Plant Tiss. Cult. Biotechnol. 22(2): 107-111.

Pradhan S., Pant B. 2009. In vitro seed germination in Cymbidium elegans Lindl. and Dendrobium densiflorum Lindl. ex Wall (Orchidaceae). Botanical Orientalis: Journal of Plant Science 6: 100-102. DOI: 10.3126/botor.v6i0.2917.

Pradhan S., Paudel Y.P., Pant B. 2013a. Efficient regeneration of plants from shoot tip explants of Dendrobium densiflorum Lindl., a medicinal orchid. Afr. J. Biotechnol. 12(12): 1378-1383. DOI: 10.5897/AJB12.2731.

Pradhan S., Regmi T., Parmar G., Pant B. 2013b. Effect of different media on in vitro seed germination and seedling development of Cymbidium aloifolium (L.) Sw. Nepal Journal of Science and Technology 14(1): 51-56. DOI: 10.3126/njst.v14i1.8878.

Rajbhandari K.P., Bhattarai S. 2001. Beautiful orchids of Nepal. Kishor Offset Press Pvt. Ltd.

Rajkarnikar K.M. 2011. Propagation of Cymbidium aloifolium (L.) Sw. in vitro by seeds. Bull. Dept. Plant Res. 33: 27-30.

Rajkarnikar K.M. 2014. In vitro propagation of Dendrobium amoenum Wall. ex Lindl. from shoot-tip culture. Bull. Dept. Plant Res. 36: 52-55.

Rokaya M.B., Raskoti B.B., Timsina B., Münzbergová Z. 2013. An annotated checklist of the orchids of Nepal. Nordic J. Bot. 31(5): 511-550. DOI: 10.1111/j.1756-1051.2013.01230.x.

Sharma S., Shahzad A., Teixeira da Silva J.A. 2013. Synseed technology - a complete synthesis. Biotechnology Advances 31(2): 186-207. DOI: 10.1016/j.biotechadv.2012.09.007.

Shrestha M., Rajbhandary S.B. 1988. Meristem culture of Cymbidium giganteum Wall Ex Lindl. National Conference on Science and Technology, April 2429, 1988, Kathmandu, Nepal, pp. 345-349. 
Shrestha M., Rajbhandary S.B. 1994. Clonal multiplication of Cymbidium longifolium D.Don by shoot-tip culture. $2^{\text {nd }}$ National Conference on Science and Technology, June 8-11, 1994, Kathmandu, Nepal, pp. 369-371.

Subedi A., Kunwar B., Choi Y., Dai Y., van Andel T., Chaudhary R.P., de Boer H.J., Gravendeel B. 2013. Collection and trade of wild-harvested orchids in Nepal. J. Ethnobiol. Ethnomed. 9: 64. DOI: 10.1186/1746-4269-9-64.

Swar S., Pant B. 2004. Influence of growth regulators on asymbiotic germination and early seedling development of Cymbidium iridioides D. Don. $4^{\text {th }}$ National Conference on Science and Technology, March 2326, 2004, Kathmandu, Nepal, pp. 1039-1043.

Swarts N.D., Dixon K.W. 2009. Terrestrial orchid conservation in the age of extinction. Ann. Bot. 104(3): 543-556. DOI: $10.1093 / \mathrm{aob} / \mathrm{mcp} 025$.
Teixeira da Silva J.A. 2012. Is BA (6-benzyladenine) BAP (6-benzylaminopurine)? The Asian and Australasian Journal of Plant Science and Biotechnology 6 (Special Issue 1): 121-124.

Teixeira da Silva J.A. 2013. Orchids: advances in tissue culture, genetics, phytochemistry and transgenic biotechnology. Floriculture Ornamental Biotechnol. 7(1): $1-52$.

Teixeira da Silva J.A., Chin D.P., Van P.T., Mii M. 2011. Transgenic orchids. Sci. Hortic. 130: 673-680. DOI: 10.1016/j.scienta.2011.08.025.

Teixeira da Silva J.A., Kerbauy G.B., Zeng S., Chen Z., Duan J. 2014. In vitro flowering of orchids. Crit. Rev. Biotechnol. 34(1): 56-76. DOI: 10.3109/07388551.2013.807219.

White K., Sharma B. 2000. Wild orchids in Nepal: the guide to the Himalayan orchids of the Tribhuvan Rajpath and Chitwan jungle. White Lotus Press. 